\title{
What's on the menu? Options for strengthening the policy and regulatory framework for the exchange, use and conservation of animal genetic resources ${ }^{1}$
}

\author{
S.J. Hiemstra ${ }^{1}$, A.G. D rucker ${ }^{2}$, M.W.Tvedt ${ }^{3}$, N . Louwaars ${ }^{1}$, J.K. O Idenbroek ${ }^{1}$, K. A w gichew ${ }^{4}$, \\ S. A begaz Kebede ${ }^{5}$, P.N. B hat ${ }^{6} \&$ A . da Silva M ariante \\ ${ }^{1} \mathrm{C}$ entrefor $\mathrm{G}$ enetic Resources, the N etherlands (CGN) of W ageningen U niversity and Research Centre, the \\ N etherlands. P.O. B ox 65, 8200 A B Lelystad, theN etherlands \\ ${ }^{2} \mathrm{~S}$ chool for Environmental Research, Charles D arwin U niversity, D arwin, A ustralia \\ ${ }^{3}$ The F ridtjof N ansen Institute, P.O. Box 326, 1326 Lysaker, N orway \\ ${ }^{4}$ Institute of Biodiversity Conservation, P.O.Box 30726, Ethiopia \\ ${ }^{5}$ A mbo College, P.O . Box. 19, A mbo, Ethiopia \\ ${ }^{6}$ W orld Buffal o Trust (WBT), $201303 \mathrm{~N}$ oida (U P), India \\ ${ }^{7}$ EM BRA PA Cenargen, Brasilia DF, Brazil
}

\section{Summary}

This paper addresses major issues and challenges for A nimal Genetic Resources (AnGR) and the livestock sector, as well as options for further development of policies or regulatory approaches. Threemain areas were identified, i) how wecan halt the further erosion of genetic diversity and promotesustainable breeding and use, ii) whether there is a need to regulatethe exchange of genetic material and iii) how to bal ance different systems of rights (e.g. sovereign rights of nations, intellectual property rights, communal rights or rights of livestock keepers).

To halt further erosion, complementary ex-situ and in-situ conservation approaches are needed and breeding and marketing of local breeds should be strengthened. Secondly, recognizing theimportance of the exchange of AnGR, broad access and responsibleand equitableexchangemechanisms should befurther promoted. Thirdly, regarding intellectual property rights, thereis a need to adapt the application of the patent system to the special circumstances inherent in animal breeding. Moreover, possiblesui generis systems should be further explored in order to better balance different rights systems.

Rather than developing a new or adapted internationally legally binding framework, the intergovernmental process under FAO may instead wish to focus, in the first instance, on the development of voluntary instruments to strengthen national policies and theimplementation of action at national levels.

Debates and developments related to international agreements in thecrop sector have also tended to framethe debatefor AnGR. However, beforelaunching into a discussion on whether or not an 'FAO A nimal Treaty' would beneeded, one should first of all clarify the problems to be dealt with and regulated via an international regime.

\section{Résumé}

Cet articlerassembleles thèmes principaux et défis des Ressources Génétiques A nimales (AnGR) et du secteur élevage, ai nsi queles options disponibles pour ledéveloppement de politiques ou règlements.

\footnotetext{
${ }^{1}$ This paper summarizes the main findings of a study entitled 'Exchange, Use and Conservation of Animal Genetic Resources: Policy and Regulatory Options'. Report 2006/ 06. Centre for Genetic Resources, the N etherlands (CGN), Wageningen University and Research Centre. The study was commissioned by FAO and funded by the Government of the United Kingdom of Great Britain and Northern Ireland, through DFID. The views expressed in the report and in this paper are the sole responsibility of the authors. The full report is downloadable from: http://www.cgn.wur.nl/U K/CGN +A nimal +Genetic+Resources/Policy+advice/ http://www.cgn.wur.nl/U K/CGN +General +Information/Publications/2006/

http://www.fao.org/ag/againfo/subjects/en/gen etics/documents/ITWG-AnGR4/AnGR_policy_and_regul.pdf
} 
On a identifiétrois domaines principaux:

1. Comment empêcher l'érosion dela diversité génétiqueet promouvoir l'utilisation et l'élevage durable.

2. Quand est-il nécessaire de réglementer les échanges dematériel génétique.

3. Xomment adapter les différents systèmes législatifs (p.e. les droits souverains au niveau national, les droits sur la propriétéintellectuelle, les droits communs ou droits des éleveurs).

Pour empêcheuneérosion ultérieure desétudes complémentairesin-situ et ex-situ seront nécessaires, ainsi qu'un renforcement dela sélection et commercialisation des races locales. En deuxième lieu, et tenant comptedel'importance des échanges deA nGR, on devrait promouvoir un majeur accès et des mécanismes responsables et équitables. Pour finir, en cequi concerneles droits dela propriété intellectuelle, il faudrait adapter I'application des systèmes de brevet aux circonstances spéciales inhérents au secteur del'élevageanimal.

Cependant, on pourrait rechercher d'autres systèmes possibles sui generis afin demieux adapter les différents systèmes législatifs. Au lieu de développer un nouveau systèmeou adapter un cadrelégal au niveau international, le procès intergouvernemental souslasupervision delaFAO voudrait centrer lethèmeen principesur le développement d'outils volontaires qui renforceraient les politiques national es et la miseen oeuvred'actions au niveau national. Les débats et développements en relation avec les accords internationaux dans le domaine agricole ont contribuéaussi à l'encadrer dans les A nGR. Cependant avant d'initier une discussion sur I'opportunitéou moins d'établir un “TraitéFAO sur les animaux" il serait nécessaire d'identifier les problèmes auxquelsil faudra faire faceet comment les réglementer à travers un accord international .

\section{Resumen}

Este artículo recoge los temas principales y desafíos delos Recursos Zoogenéticos (AnGR) y del sector ganadero, así como las opciones para el consiguientedesarrollo de políticas o reglamentos. Seidentificaron tres áreas principales:

1. Cómo impedir la erosión dela diversidad genética y promover la utilización y cría sostenible.

2. Cuando es necesario reglamentar los intercambios dematerial genético.
3. Cómo adaptar los distintos sistemas legales (p.e. los derechos soberanos a nivel nacional, los derechos dela propiedad intelectual, los derechos comunales o derechos delos ganaderos).

Para impedir una erosión ulterior serán necesarios estudios complementarios in-situ y ex-situ, así como un reenforzamiento dela cría y comercialización de las razas locales. En segundo lugar, teniendo en cuenta la importancia de los intercambios de AnGR, sedebería promover un mayor acceso y mecanismos responsables y equitativos. Por fin, en lo relativo a los derechos de la propiedad intelectual, sería necesario adaptar la aplicación del sistemas de patentes a las circunstancias especial es inherentes al sector de la cría animal. Sin embargo, se podrían investigar ulteriores posibles sistemas sui generis con el fin de adaptar mejor los distintos sistemas legales. En vez de desarrollar un nuevo sistema o adaptar un marco legal a nivel internacional, el proceso intergubernamental bajo supervisión dela FAO desearía enfocar el tema en un principio en el desarrollo deinstrumentos voluntarios que reforcen las políticas nacionales y la implementación de las acciones a nivel nacional. Los debates y desarrollos relacionados con los acuerdos internacionales en el sector agrícola también han contribuido a enmarcar el debateen el campo deA nGR. Sin embargo, antes delanzarse en una discusión sobre la oportunidad o menos deestablecer un "Tratado dela FAO sobre animales", se deberían identificar los problemas queseencontraran y cómo reglamentarlos a través de un acuerdo internacional.

Keyw ords: AnGR, Policy and Regulatory 0 ptions, Exchange, Conservation, U se, Rights.

\section{Introduction}

TheFAO International Technical Conferenceon A nimal Genetic Resources (AnGR) in Interlaken in 2007 will represent a milestone, finalizing the global assessment on the State of the World's Animal Genetic Resources and providing an opportunity to reach agreement on how best to address priorities for the sustainable use, development and conservation of animal genetic resources for food and agriculture (AnGR). Oneof theexpected outcomes of this Conferenceis a Global Plan of Action on A nimal Genetic Resources, therefore Interlaken will probably befor A nGR what Leipzig was for plant genetic resources for food and agriculture. Theoverall process, coordinated by 
FAO and driven by national governments, should result in action contributing to conservation and sustainable breeding and utilization of AnGR. It is expected that threeimportant issues need to be discussed:

1. How wecan halt thefurther erosion of genetic diversity and promotesustainable breeding and use.

2. Whether thereis a need to regulatetheexchange of genetic material.

3. How to better balance different systems of rights (e.g. sovereign rights of nations, intellectual property rights, individual or communal ownership rights or access rights to AnGR and natural resources).

Debate on theseissues may lead to a decision as to whether an international legally binding mechanism is needed, or if 'softer' arrangements can adequately meet theobjectives in a more effectivemanner.

Although not designed primarily for A nGR, international agreements with a general scope (governed by the Convention on Biological Diversity (CBD), theWorld TradeOrganisation/ Trade Related Intellectual Property System (WTO/ TRIPS) and the World Intellectual Property Organisation (WIPO)) also apply to A nGR. As their implementation advances further, they may havean increasingly significant impact on A nGR exchange, use and conservation. While the special nature of agricultural biodiversity is recognized, FAO could play a key role in facilitating and informing the debateon specific AnGR needs and challenges.

In 2004, the Intergovernmental Technical Working Group on A nimal Genetic Resources ${ }^{2}$ recommended that FAO commission a study ${ }^{3}$ to assess how exchange practices regarding A nGR affect the various stakeholders in thelivestock sector, and to identify policies and regulatory options that guidetheglobal exchange, use and conservation of AnGR. This paper presents the main findings of the recommended study: policy and regulatory options related to the exchangeand the conservation and sustainable use of AnGR. The identification of options is based on literature surveys ${ }^{4}$ and stakeholder consultations. A review of thecurrent situation and theexploration of future scenarios served as input for the latter. ${ }^{5}$

\section{The International Treaty on Plant G enetic Resources (PG R) for Food and Agriculture as an example for A $\mathbf{n G ~ R}$ ?}

Debates and developments related to international agreements in the crop sector haveal so tended to framethe debatefor AnGR. Somearguethat it is important to develop a legally binding international agreement for A nGR similar to the International Treaty on Plant Genetic Resources for Food and A griculture(ITPGRFA) that has been ratified by a growing number of countries. Coreelements of this treaty area multilateral system for the exchange of accessions of plant genetic resources for food and agricultureand the recognition of farmers' rights which are left to countries to implement. Thetreaty is in line with CBD and regulates specific aspects for plant geneticresources in agriculture. Before launching into a discussion on whether or not an 'FAO A nimal Treaty' would beneeded, oneshould clarify which problems need to beregulated or which trends needed to be positively influenced. Key biological, historical, socio-economic and institutional differences between plant and animal genetic resources need to be understood and to be brought into the policy, regulatory and legal discussions about AnGR. The substantial differences between animal and plant breeding

\footnotetext{
${ }^{2}$ CGRFA/ WG-A nGR-3/ 04/ REPORT, paragraph 24

${ }^{3}$ The study, entitled 'Exchange, use and conservation of animal genetic resources: policy and regulatory options' was commissioned by FAO and funded by the Government of the United Kingdom of Great Britain and Northern Ireland, through DFID. The views expressed in the report and in this paper are the sole responsibility of the authors. The full report is downloadable from: http://www.cgn.wur.nl/U K/CGN +A nimal+Genetic+R esources/Policy+advice/ http://www.cgn.wur.nl/U K/CG N +General +Information/Publications/2006/ http://www.fao.org/ag/againfo/subjects/en/genetics/documents/ITWG-AnGR4/AnGR_policy_and_regul.pdf

${ }^{4}$ Due to the large number of references, they are listed in the Bibliography section at the end

${ }^{5}$ For further details about future scenario's and stakeholder analysis see also Drucker et al. (this volume); a detailed analysis of property rights, exclusive rights and use rights is provided by Tvedt et al. (this volume).
} 
strongly suggest that to simply copy the solutions from the plant sector to theanimal branch will not providea suitablesolution.

\section{H alt Further G enetic Erosion and Promote Sustainable Breeding and U se}

There is consensus that global AnGR diversity is under pressure. The global livestock sector is increasingly focused on a small number of highly specialized breeds and local breeds are threatened. The existence of threats to farm animal breeds and farm animal genetic diversity is generally accepted,

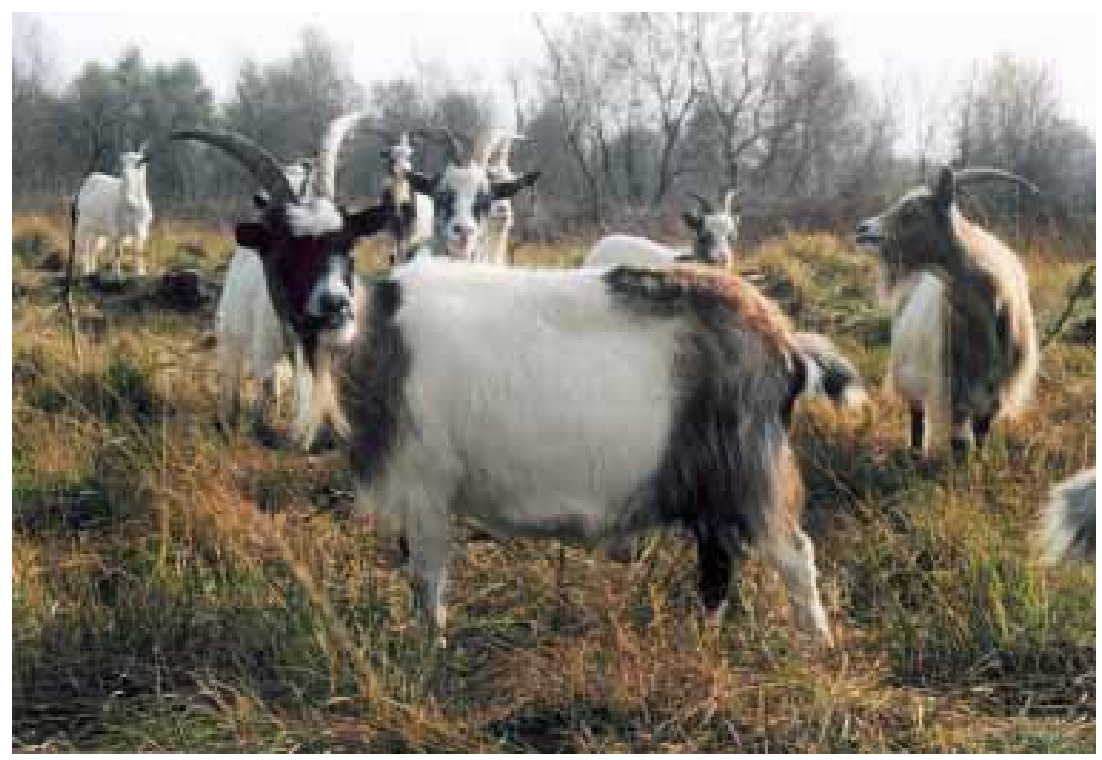

Even wherediverseanimal genetic resources currently have a low 'direct use' value, such resources may nonetheless be particularly valuable for future use. Such 'non-market' values providea key justification for the public sector to play an important rolein their conservation and management. However, thereis limited awareness about theimportance of conservation and the sustainableuse of AnGR among policy makers and major stakeholders in thelivestock sector.

To halt further geneticerosion, complementary ex-situ and in-situ conservation approaches are needed, to beorganized at national, regional and/ or global levels. Themajor responsibility for the conservation and sustainable use of AnGR lies at thenational level (according to the CBD).

However, coordination and collaborativearrangements at regional and/ or global levels are also likely to beimportant.

Ex-situ conservation could either supportin-situ conservation and breeding in the short termor may havea long term (insurance) objective. Ex-situ approaches requireappropriate infrastructure, organization, technical capacity, agreed priorities, sustained funding and (new) legal arrangements regarding ownership and the use of germplasm.

In many countries there is a lack of human resources and institutional capacity in animal breeding. Lack of effective, sustainable breeding programs

Figure 1. D utch Landracegoat, the N etherlands (photo by H.F. Cnossen).

even though debateremains about the severity of genetic erosion. FAO (2007) reported that, globally, $20 \%$ of recorded breeds are classified as 'at risk'. On the other hand, the loss of breeds is only one indicator of the loss of farm animal genetic diversity, as a major part of genetic diversity is found within breeds and there is al so significant genetic overlap between breeds. Maintenance of within breed diversity is as important as between breed diversity as a genetic reservoir for future breeding and use. Both commercial breeds and rare breeds sometimes havevery limited within breed diversity. Therefore, the problem may bebigger than figures of breed loss imply. for local breeds may be one of the reasons that such breeds lose their competitive advantage, especially where production systems or external conditions aresubject to change. Poor marketing and breed promotion is al so an important limiting factor for the continued use of valuable breeds. Without interventions and thestrengthening of breeding capacity for local breeds, thecurrent threat to the survival of local AnGR is inevitably going to escalate. Within-breed diversity in both local and international breeds may also declinewithout proper consideration of inbreeding issues and sustainablelong term breeding goals. 


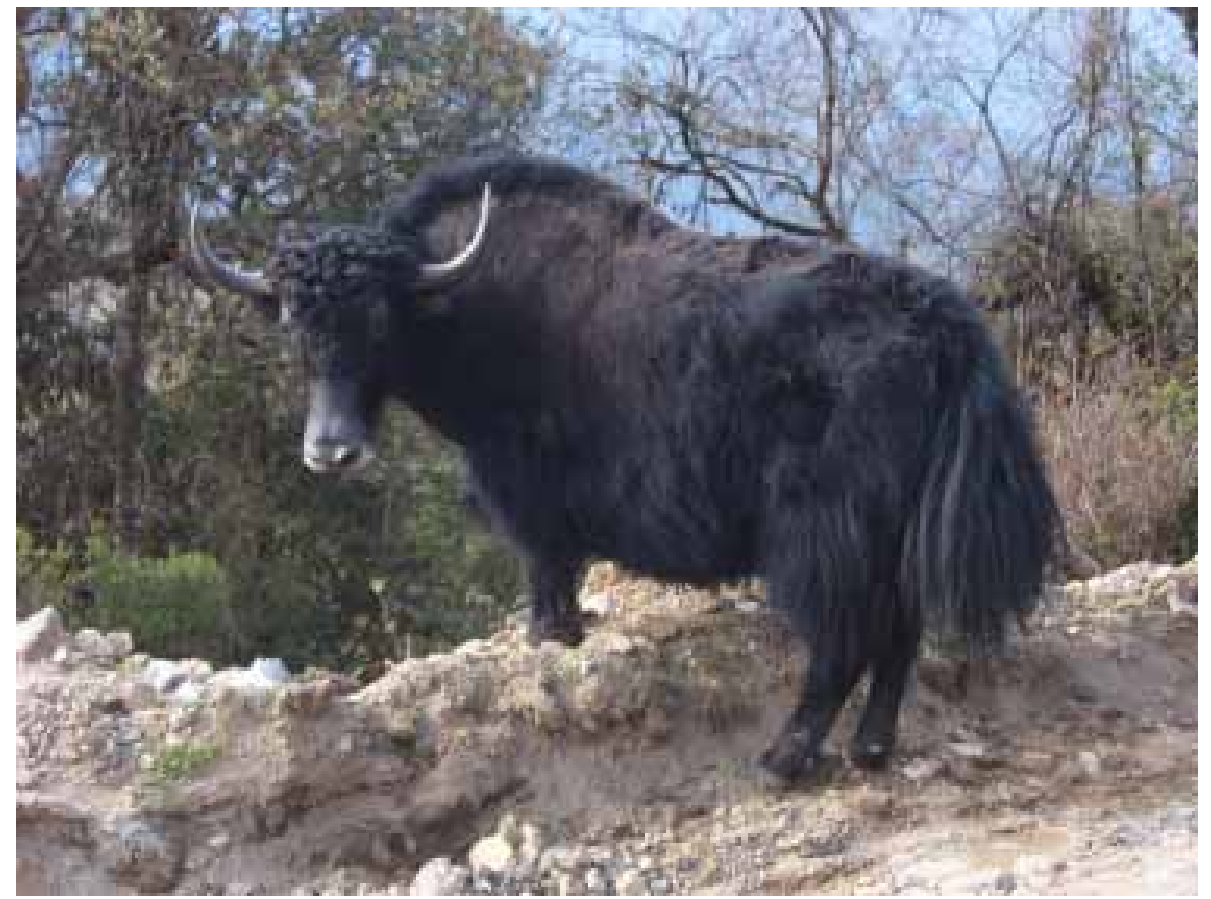

(by privatelaw contracts and customary law) and is also influenced by zoosanitary regulations. Some countries havespecific access regulations or regulations to assess the potential impact of AnGR introductions in the country.

\section{Zoo-sanitary regulations}

Zoo-sanitary regulations areconsidered to bethe main constraints to exchange. In order to avoid frustrating the exchange of AnGR, further harmonization of

Figure2. Yak, Bhutan (photoS.J. H iemstra).

\section{Responsible and equitable exchange mechanisms}

Exchange of genetic material between countries and regions over millennia has been a very valuable mechanism for breed and livestock development. Countries and regions arehighly interdependent, and continue to need broad access to A nGR for their livestock development. However, therehavealso been director indirect negativeeffects on farm animal genetic diversity.

A tremendous amount of AnGR exchange currently takes place between developed countries ('N orth' to 'North') whileglobalization drives the exportation of high performing breeding stock from 'North' to 'South'. 'South' to 'South' exchange has also been extensive and important for livestock development but less well documented than 'North' to 'N orth' exchange. Movements of livestock germplasm from 'South to N orth' have been rarein the past century. Thelatter practiceis in stark contrast to plants, where South to N orth flows are prominent, driven by the search for disease resistance and adaptive genes for new plant varieties. This important differencein thegeneflow direction is likely to influence discussions on the regulation of exchange.

The exchange of AnGR is currently mainly regulated through the transfer of privateownership zoo-sanitary laws should continue at regional and global levels. Special attention should begiven to theuse of resources cryo-conserved in the past.

\section{Impact assessment}

Thereare examples of the damaging effects of introducing exotic material from $\mathrm{N}$ orth to South to improvelocal breeds. Theexistence of genotype $x$ environment interactions, and the avoidance of undesired effects of exchange, may trigger theneed to assess the (genetic) impact of import/ export on sustainable(livestock sector) development in thecountry. Such an instrument may beworth considering as a basis for putting in placestrategies to support the mitigation of potential negativeside-effects of particular exchange practices. A pplication of a (voluntary) 'code of good practice' would beuseful in this context, creating stronger responsibilities for both exporters and importers. Genetic impact assessments (both positiveand negative) could al so beextended to includeeconomic and livelihood impacts as well as other developmental and/ or environmental impacts. A potential disadvantage that would haveto beovercomeis thelikelihood of increased bureaucracy, thereby blocking imports and reducing livestock sector development opportunities. 


\section{Access and benefit sharing}

It is a general belief that thecurrent exchangeof AnGR has generated benefits for both seller and buyer under the present circumstances where privatelaw agreements havebeen in use. However, therearesomecases wherestakehol ders consider that benefit sharing has not been sufficiently catered for. Thereare cases wherethevaluein further breeding turned out to significantly outweigh the purchasevalue of theexported breeding animal or germplasm. The CBD presupposes theright of a country to exercisesovereign control over its AnGR (accompanied by a number of responsibilities). An exporting country may wish to maintain property rights over the AnGR after the resources havel eft the country. Even if theanimals and breeding material are under privateownership, states have, according to the CBD, theright to regulateexport. It can beargued that privateparties agree on benefit sharing when AnGR is being transferred by a privatelaw agreement. An export regulation could however set rules or a minimum standard for the content of a privatelaw agreement to beconsidered legal or valid.

An export regulation could providea useful supplementary tool for privatelaw agreements, in particular in situations where negotiating capacities or market positions aresignificantly unequal. Two countries who commonly trade AnGR could also decide to develop a bilateral framew ork agreement aimed at facilitated exchange, following a prenegotiated set of rules.

Development of a model $M$ aterial Transfer A greement (model MTA) at theinternational level,

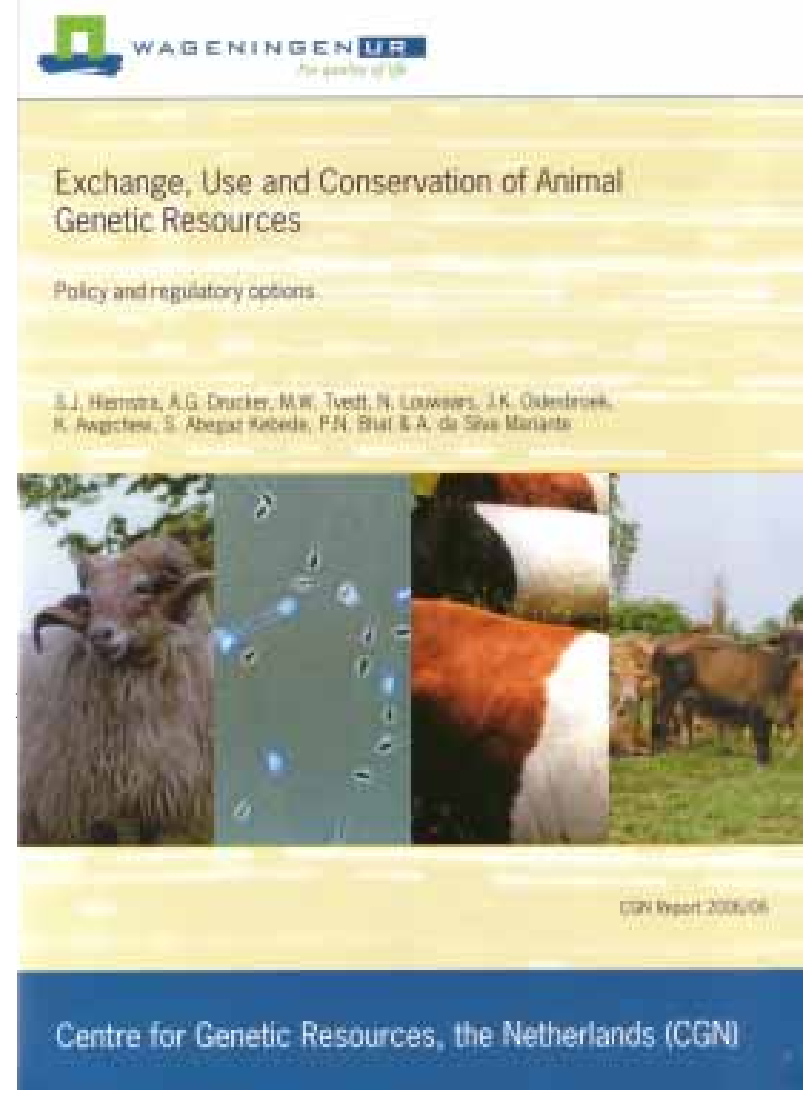

Figure 3. Cover of the Report "Exchange, use and conservation of animal genetic resources: policy and regulatory options". Report 2006/06.

largely based on current exchange practices as well as covering all important negotiation issues relevant to AnGR exchange, would also be useful, in order to support the responsibleexchange of AnGR. Development of such a model M TA may becomeparticularly important if patterns of geneflow were to change substantially in thefuture. Privatelaw guided exchangecould besupplemented by a model M TA which would supplement thefragmented use of contracts today.

Following the negotiations in the CBD regarding an International Binding Regimefor Access and Benefit Sharing, there is a need to survey how these changes in the international legal order for the exchange of genetic resources in general will affect
Figure4. Groningen W hiteH eaded cattle, the N etherlands (photo by H.F. Cnossen). 
the exchange of AnGR in particular. Development of an international agreement on a standard M TA for AnGR could bea responseto CBD developments and to unequal negotiating capacities and the market dominance of larger commercial entities in thelivestock sector. A MTA for AnGR should reflect thesignificant differences between plant and animal genetic resources.

\section{Intellectual Property Rights and Use Rights}

Genetic flows havechanged over time, genetic diversity is under pressure, and thepower between stakeholders is increasingly unbalanced. Further concentration and vertical integration in the livestock industry, combined with the protection of investments through the use of intellectual property rights aregenerating an increased concern about equity and may seriously affect the positions of livestock keepers, small farmers and (small scale) breeders.

Today, al mostall farm animal genetic resources areunder private control and ownership and not considered to bein the public domain. However, breeds are 'public' in the sense that governments often recognizethem as distinct breeds. Commercial breeders generally 'protect' their investments by 'staying ahead' of competing breeders, through physical control of theuse of their breeding animals and the use of privatelaw contracts. The use of Intellectual Property Rights (IPR) in animal breeding has to datemainly been focused on trademarks. Developments in patenting in some countries havetriggered discussions about the potential impact of patenting on animal breeding methods and animal genes and cells. This has also started a discussion about theneed to definethe rights of livestock keepers/ farmers/ breeders over the AnGR they havedeveloped over timeand about access rights to $A n G R$ and natural resources. An increasing tension is apparent between existing physical ownership or communal ownership to AnGR and increased use of the patent system in the commercial breeding sector. Regarding developments in the patent system, concerns have been raised that a high number of patent claims and the broad scope of the claims may lead to a significant body of exclusiverights on knowledge and breeding technology with substantial impacts on theuse of AnGR.

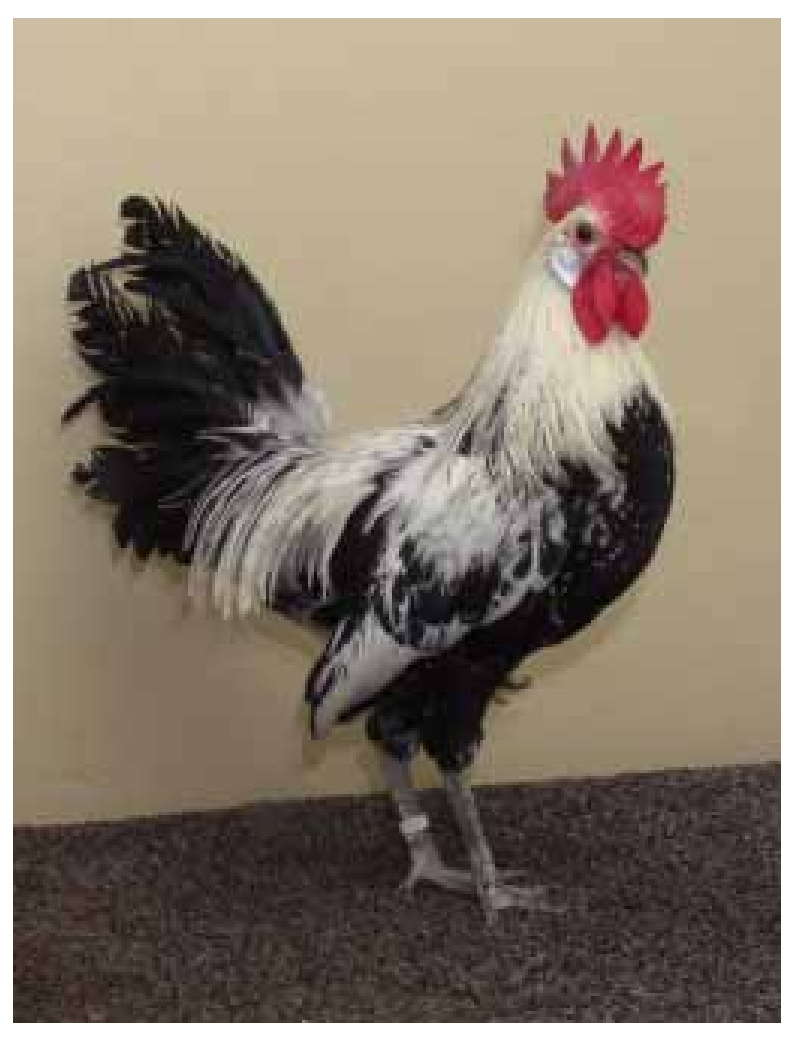

Figure 5. D renthefowl, the N etherlands (photo by F. van W elie).

\section{Exclusive rights}

There is considerableconcern that patents be granted to existing methods - although they may not sufficiently disclosed to qualify as prior art in thepatent system. To counterbalancethe effect of excessive patenting, preventivepublishing is often put forward as a strategy to ensurethat common knowledgewill beconsidered prior art. However, theability to exploit even small adaptations to what was originally published (i.e. 'patenting around the prior art') means that such an approach may bean ineffectivecounterbalancein practice. Other alternatives could beto oblige patent offices to take into account specific AnGR prior art/novelty/ inventiveness guidelines and/ or having countries introduce specific exemptions in national patent law, such as farmers' privilege or breeder's exemption. A systematic legal analysis would beadvisable to assess how general patent law rules apply to AnGR and breeding. There is also a need for analyzing the effects patents might have on research and investments in the animal sector; and eventually it may beworth considering the degreeto which patent protection is needed at all in the animal 
sector, to promotebreeding, research and development in thelivestock sector.

\section{Sui generis protection}

The present system of plant breeders' rights (UPOV) provides protocols for assessing and describing the uniquecharacteristics of a new plant variety, ensuring that it is distinct, uniform and stable. Such a system is unlikely to beapplicable to farm animal breeds in the same way as it is for plants. Sui generis protection systems could nonetheless beuseful. Establishment of breed associations or herd book registration (governed by breeding laws) combined with trademark protection would bea good alternativefor breed conservation and property right protection. A sui gen eris protection could also belinked to special geographical related properties and characteristics of the animals or their products (geographical indications).

\section{Conclusions}

Based on analysis of the existing policy frameworks, and as potential solutions to the problems raised during thestakeholder consultations, a number of possiblepolicy and regulatory options for $A n G R$ wereidentified during thestudy. Theseshould beconsidered within the context of an informed debater regarding theneed for strengthening theexisting policy and regulatory framework for AnGR, as well as in terms of theform that any such strengthening should take. With regard to thelatter, rather than developing a new or adapted internationally legally binding framework, theintergovernmental process under FAO may instead wish to focus, in the first instance, on the development of voluntary instruments to strengthen national policies and theimplementation of action at national levels. This could becarried out in parallel with further analysis of how other international regimes may influenceAnGR. The Interlaken Conferenceis expected to raisethelevel of awareness on themany roles and values of $A n G R$, and to highlight the special nature of $A n G R$, their distinctivefeatures, and problems needing distinctivesolutions.

\section{Acknowledgements}

Wearegrateful to FAO for commissioning this study, and to the Government of the United Kingdom of Great Britain and N orthern I reland for funding it through the Department for International DevelopmentDFID. Weal so thank themembers of thesteering committee, I. Hoffmann (FAO) and T. Brown (DFID) for their inputs and contributions.

\section{List of References}

CBD . 1992. Convention on Biological Diversity. A vailableat: www.biodiv.org.

CBD. 2002. Bonn Guidelines on Access to Genetic Resources and Fair and EquitableSharing of the Benefits A rising out of their Utilization.

D rucker, A .G ., V. G omez \& S. A nderson. 2001. TheEconomic Valuation of Farm A nimal Genetic Resources: A Survey of A vailableMethods. Ecological Economics. Vol. 36 (1): 1-18.

\section{D rucker, A .G ., M . Smale \& P. Zambrano.} 2005. Valuation and Sustainable M anagement of Crop and Livestock Biodiversity: A Review of Applied Economics Literature. SGRP/ IFPRI/ ILRI, www.ilri.org.

Esquinas-A lcazar, J. 2005. Protecting crop genetic diversity for food security: political, ethical and technical challenges. Science $\&$ Society: $N$ ature Review Genetics 6, 946-953.

FA O. 1999. The gl obal strategy for the management of farm animal genetic resources. FAO. Rome.

FA 0. 2005. The legal framework for the management of animal genetic resources. FAO LegislativeStudy 89. ISSN 1014-6679. ISBN 92-5105433-9. Ingressia, A., Manzel la, D. \& Martyniuk, E. (Eds), Food and A griculture Organization of theUnited Nations, Rome, 2005.

FA 0. 2007. The State of the World's A nimal Genetic Resources. B. Rischkowsky and D. Pilling (Eds).

G ibson, J.P. \& S.V. Pullin. 2005. Conservation of Livestock and Fish Genetic Resources. Gibson, J.P. and Pullin, S.V. Science Council Secretariat, FAO. 
Gibson, J ., S. G amage, O. H anotte, L. Iñiguez, J.C. M aillard, B. Rischkowsky, D. Semambo \& J. Toll. 2006. Options and Strategies for the Conservation of Farm A nimal Genetic Resources: Report of an International Workshop (7-10N ovember 2005, M ontpellier, France). CGIAR System-wideGenetic Resources Programme (SGRP)/ Bioversity International, Rome, Italy, pp. 53.

Hiemstra, S.J ., A.G . D rucker, M.W. Tvedt, N. Louwaars, J.K. Oldenbroek, K. A wgichew, S. A begaz Kebede, P.N . Bhat \& A. da Silva $M$ ariante. 2006. Exchange, use and conservation of animal genetic resources: policy and regulatory options. Report 2006/ 06. Centrefor Genetic Resources, theN etherlands (CGN), Wageningen University and Research Centre, theN etherlands; www.cgn.wur.nl/U K/CGN +A nimal+Genetic+Resources/ Policy+advice/; http://www.cgn.wur.nl/UK/ CGN +General +Information/Publications/2006/; www.fao.org/ag/againfo/subjects/en/genetics/documents/ ITWG AnGR4/AnGR_policy_and_regul.pdf

H offmann, I.\& B. Scherf. 2005. Management of farm animal genetic diversity: opportunities and challenges. WAAP Book of the Year 2005, pp. 221-245.

ITPG RFA . 2004. International Treaty on Plant Genetic Resources for Food and A griculture, FAO, Rome, 2004. Aavailableat www.fao.org (full weblink).

LID . 1999. Livestock in poverty-focused development. Livestock in Development. Crewkerne, UK.

LPP. 2003. Karen Commitment. Pastoralist/ Indigenous Livestock Keepers' Rights. Karen, Kenya, 27-30 October, 2003; www. pastoral peoples.org/ docs/karen.pdf.

Mathias, E. \& P. M undy. 2005. Herd movements: Theexchange of livestock breeds and genes between North and South. Leaguefor Pastoral Peoples and Endogenous Livestock Development; www. pastoral peoples.org/docs/ herdmovements.pdf

N otter, D .R. 2004. Conservation strategies for animal genetic resources. Background Study Paper No. 22. Commission on Genetic Resources for Food and Agriculture, FAO, October 2004.
Rege,J.E.0.\& J.Gibson. 2003. A nimal genetic resources and economic development: issues in relation to economic valuation. Ecological Economics 45 (3), 319-330.

Rosendal, G .K., I . Oleson, H .B. Bentsen, M .W. Tvedt \& M . Bryde. 2005. Strategies and Regulations Pertaining to Access to and Legal Protection of Aquaculture Genetic Resources. The Fridtjof N ansens Institute, October 2005.

Rothschild, M .F., G. Plastow \& C. N ewman. 2003. Patenting in animal breeding and genetics. WAAP Book of the Year 2003, pp. 269-278.

Sainath, P. 1996. Everybody Loves a Good Drought. Stories form India's Poorest Districts. Penguin Books, 1996.

Sere, C., H . Steinfeld \& J . G roenew old. 1996. World Livestock Production Systems. Current status, issues and trends. FAO A nimal Production and Health Papers 127. FAO. Rome, Italy.

Stannard, C., N . van der G raaf, A . Randall, P. Lallas \& P. Kenmore. 2004. A gricultural biological diversity for food and agriculture: shaping international initiatives to help agriculture and theenvironment. Howard Law Journal, vol. 48, no. 1. Ed. Howard University School of Law.

Steinfeld, H ., P. G erber, T. Wassenaar, V . Castel, M . Rosales \& C. H aan. 2006. Livestock's long shadows. Environmental issues and options. FAO; www.virtualcentre.org/en/library/key_pub/ longshad/A 0701E00.pdf

Tisdell, C. 2003. Socioeconomic causes of loss of animal diversity genetic: analysis and assessment. Ecological Economics 45 (3), 365-376.

TRIPS. A greement on Trade-Related A spects of Intellectual Property Rights; availableat: www.wto.org.

Tvedt, M .W. 2005. How will a substantive patent law treaty affect the public domain for genetic resources and biological material? The Journal of World Intellectual Property, vol. 8no. 3, 311-344.

Tvedt, M .W. 2006. Element for Legislation in User Country to M eet the Fair and EquitableBenefitSharing Committment. The Journal of World Intellectual Property, vol. 9, no. 2., 189-212. 
Tvedt, M.W.\& T.R.Young. 2006

(Forthcoming). Beyond Access-A Legal Analysis of theFair and EquitableBenefit Sharing Commitment in the CBD. IUCN.

UPOV. 1991. International Union for the Protection of New Varieties of Plants; availableat www.upov.int.

Valle Zárate, A., K. M usavaya \& C. Schäfer. 2006. Geneflow in animal genetic resources. A study on status, impact and trends. Institute of A nimal Production in the Tropics and Subtropics, University of Hohenheim, Germany.
Verrier, E., M. Tixier-Boichard, R. Bernigaud \& M . N aves. 2005. Conservation and value of local livestock breeds: usefulness of nicheproducts and/ or adaptation to specific environments. A nimal Genetic Resources Information, no. 36, 2005.

Woolliams, J. \& M. Toro. 2007. What is genetic diversity? In: Utilisation and Conservation of Farm A nimal Genetic Resources. K. Oldenbroek (Ed.). Wageningen A cademic Publishers. 